Natalia Victorovna Kuznetsova, $\mathrm{PhD}^{1}$

Natalia Alexandrovna Vorobeva, $\mathrm{PhD}^{2}$

School of Economics and Management,

Far Eastern Federal University, Russia
SCIENTIFIC REVIEW ARTICLE

Received: January 23, 2015

Accepted: February 11, 2015

\title{
ANALYSIS OF GLOBAL INTEGRATION PROCESSES: SOUTH AFRICA, ASIA-PACIFIC REGION AND RUSSIA ${ }^{3}$
}

\begin{abstract}
The paper examines the problem of global integration proces s in regio of Africa, Asia and Russia. Based on migration flows, estimation onteg, tion ind ies, we investigate the historical integration development of th e regions o d i cntify the important features for future international coopera. $y$ an integration. This article presents the preliminary results of the gravi moa hat wo constructed using the features of Asia-Pacific region. We luded th ferences and similarities in sectoral structure of GDP do not infunce increasing of mutual trade between countries and its partners paluates tontial benefits for Asia-Pacific region by expanding the ma let for export industries worldwide.

Keywords: global integration proces gravity lodel, ASEAN, Asia-Pacific Region, economy of North-East integr of South Africa

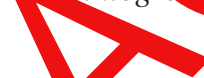

JEL classification: F6, R11

АНАЛИЗА ГЛОБ ЛНУ МНИЕГРАЦИОНИХ ПРОЦЕСА: ЈУЖНА АФ ИК РЕГИОН АЗИЈЕ И ПАЦИФИКА И РУСИЈА

Апстракт

У ду с разматра проблем глобалних интеграционих процеса у регионима Аһпике, sије и усије. На основу миграционих токова и процене индекса ант раии, тражује се историјски развој интегращије ових региона и иде сиикуу важне карактеристике за будућу међународну сарадюу и пеграйуy. Овај рад презентује прелиминарне резултате гравитащионог модела

1 ipatovanat@mail.ru

2 natavladiv@yandex.ru,

3 Acknowledgement: The authors acknowledge receiving support from state-funded research program of Russian Ministry of Education and Science. The results of this research were achieved within the frameworks of the governmental assignment of Russian Ministry of Education and Science in the sphere of scientific research during the researching assignment \# 26.1478.2014/K "The structural transformation of Russian Economy through the integration installation in the industrial markets of Asia-Pacific Region"
\end{abstract}


који смо конструисали на основу карактерситика региона Азије и Пацифика. Закључили смо да разлике и сличности у секторској структури БДП не утичу на повећање међусобне трговине између земаља и юихових партнера. Оцењене су потенцијалне користи за регион Азије и Пацифика од иирења тржжита за извозне делатност ииром света.

Кључне речи: глобални интеграџиони процес, гравитациони модел, ASEAN, регион Азија-Пацифик, привреда североисточне Азије, процес интеграција Јужне Африке

\section{Introduction}

At the beginning of the XXI century the integration uni is, as re resy of globalization and regionalization of the world economy, is grad ally tronsfon Into a new economic and political centers that define the vector of de $\mathrm{op}^{\mathrm{r}} \mathrm{cht}$ in the regional and global scales. According to the WTO researchers in 013 , the was estimated order of hundreds of regional integration groups all or world. nowadays, the researchers estimate the regions of Africa, Asia-Pacific regio, and Russia, as one of the most perspective areas of the future integration ocoss.

Under the conditions of the WTO, the $e$ tended prations of globalization and the expansion of the USA in the Middle East and $N$ rth Africa the main European countries were forced to find ways to maintain the influen in the gion and to create sustainable mechanisms to promote their interests, now a new format - as a single integration group. Historically, Africa has a long his ry of tmintegration process, which based on the historical development of $t^{\prime}$ s 1 ion, $c$ pecially in after-war period.

The economy of As Pacific rion reates a barrier for the global integration processes. There is the $\mathrm{mm}$ of thearlier established type of bilateral relations, burdened by the legac of hostilis and deep political differences. Nevertheless, a new style of mutual cooperat is is adually thed among the countries. This style is characterized by the developp ant of econ nic relations that overcome ideological barriers.

Howe or, this issue is no univocal and that's why discussed by many authors. Some authors wr that East Asian community doesn't act in the interests of a corporate East Asian inatity t pursy objectives of individual countries (Jones \& Smith, 2007). During var as pe lods a de authors noted a low level of economic integration in Northeast A 9 , bec aso the lack of strong developed regional institutionalization processes. AsiaPaci conomic Cooperation (APEC) is noted to be the most successful among various regiona roupings (Higgott, 1998; Aggarwal \& Yamazawa 2000; Ravenhill, 2002).

However, it is clear for many observers of East Asian regionalism that such integration is inefficient. The possibility of replacing the formal institutionalization processes by regional economic integration (Ernst, 1997; Encarnation, 1999), both inside and outside of the region (Dent, 2003) is considered.

The history of the institutionalization of the integration processes shows that significant efforts were made to build strong institutional environment for the development of regional economic relations in postwar East Asia and in Africa, but these efforts were not successful (Calder \& Ye, 2004). The idea of establishing the Institute for Regional 
Cooperation under the name "The Council of the North-East Asia Regional Economic Cooperation (CNAEC)" was first published by Lee (2000).

The fact that integration in Northeast Asia will lead to the increase of the potential benefits to the countries due to economies of scale through the expansion of the export industries (Milner, 1997; Chase, 2003; Pempel, 2008), reduction of the transaction costs between the contracting parties and diminution of the importance of political negotiations (Aggarwal \& Ravenhill, 2001) is the subject of many economic discussions. The ambiguity of interpretations of the integration processes in Northeast Asia was the impetus leading to the necessity to assess the potential and the actual state of the integration processes in this region.

The reason for extensive economic evaluation is that integration Asia could increase the potential economic benefits to countries due to se scale fect, by expanding the market for the export industries (Milner, 1997; K. A Chase, 2 03; Pempel, 2008), the reduction of transaction costs between the cracting rrtie and the decline in the importance of political negotiations (Aggarw \& Ra cnhill, 01).

The core of North-East Asia is composed of China, Ja an, outh Krea. These countries contribute to the framework of the "East Asian ommun.", well as to the security mechanism in North-East Asia (NEA).

\section{Methodd ogy}

The methodological framewor nsists aditional methods, which are characteristic for the research of the obje ts ot national relations. Thus, for example:

- method of historical agies, ach approximates the theoretical arguments to the current sity an an is to reveal the dynamics of Asia-Pacific region as a livins chan $\mathrm{ng}$, time entity with all its consequences;

- method of mpara e analysis, which allows on the basis of specific data observin a general h tures of Asia-Pacific Region's relations with Russia;

- forecasting mo hod that allows to identify the main trends and prospects of rel cons;

- stema method, which shows the rate of development of relations and co $n$ ation batween Russia and Asia-Pacific region as a certain evolving

Systo hig arghting its basic elements; and it was also analyses the integration
1 South Africa.

Systo hig arghting its basic elements; and it was also analyses the integration
1 South Africa. econom statistical, logical, conceptual analysis and others type of analysis, which allow constructing a complete system of modern Russian relations with countries of Asia-Pacific region and countries of South Africa.

\section{Results}

Development of integration process in South Africa. At the beginning of the analyses of the global integration process, it's obvious to identify the main aspects of 
modern development of integration. Integration is the economic process of mutual adaptation, expansion of economic and industrial cooperation, pooling of national economies of two or more countries. The main problem of the international integration process is the creation of a single economic area within which it will ensure the freedom of movement of goods, services, capital and labour.

Thus, between two countries, there are a consistent, regular structural relationships during which countries moving away from economic and trade relations to forms of international co-production and closer financial cooperation. During this process gradually disappear a line between domestic and international markets and a new market of integration association develops. However, such situation occurs in the theory, in practice, this process is not so easy; there are many contradictions bety ational economic interests of the countries.

The integration process in Africa dates back to the beginning of $50-1960 \mathrm{~s}$ the period of political independence. At that time it was created f $/$ integra on $y$ ons, which was examined as a key area of economic developm it of cican untries liberated from colonial dependence, it was the instrument re ro and in gration of national economies into the world economy.

The important role in the process of initiatin the tegration agreements was played by the United Nations Economic Commission for Afrio (ECA), which called for the country to provide the policy of import sul utution in ordervo reduce dependence on the outside world and the "self-reliance po cy", it wa the acceleration of economic development. Following the recommendations o the ECA amework of the Organization of African Unity (OAU, 1963) was b on the regionalism and it was defined strategic goal of creating the $\mathrm{Co}$ mo r frican Union.

The next stage of integration proce Africa can be regarded as the Lagos Plan of Action (1980) the formatio of th Pan- frican common market by 2000 years, based

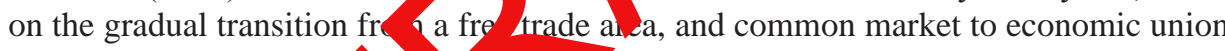
in the three sub-regions Eas Aica and South Africa, Central Africa and West Africa. The core of this inte ation was lected the leading association unions - the Common Market for Eastern and S thern Aníca (COMESA), the Economic Community of West African States, ECOWAS, nd the Economic Community of Central African States (ECCAS)

One th latest African economic development plans is the New Partnership for $A$ Do lopp (NEPAD), which aimed at promoting the mutual trade and in stmen relatio, coordination of national economic policies.

T bas of NEPAD are two programs Millennium Partnership for the African Reco ry Program (MAP) and the Omega Plan. The first program is aimed at resolving inter-Ah an conflicts, attraction of investments, and financial assistance. The Omega Plan proceeds from the priority of development, such spheres as agriculture, education, health and infrastructure objects. The merging of the two programs has led to the development of a single program called the (New African Initiative (NAI), approved in July 2001 during the Summit of Heads of State and Government of the Organization of African Unity. The final version of the New African Initiative, appeared in October 2001 and it was renamed NEPAD.

During the period before 1990s integration unions in Africa were mainly focused on mutual economic cooperation, the formation of a large market, increasing the state's 
role in economic development of a huge group of states. This period was named "new regionalism period in Africa". It differed by increasing attention to the revival of the liberalization measures under the previously established groups, as well as the formation of new groups.

Integration unions in Africa were created in conditions of extremely low level of economic development of African countries, the low share of mutual trade, and the common type of monoculture export commodity structure, the low volume tax revenues. These factors determine the disintegrating and formal type of integration processes in Africa, low dynamic and static effect of 'trade creation', and the majority of unions differs from the effect of 'trade diversion'. In such circumstances, regional integration is seen as the instrument of trade liberalization: the customs give about $30 \%$ evenue of the national budget, which hampers the liberalization process at the n? onal levo and membership in this union imposes some certain obligations and it allow finding her sources of income instead of duties.

The first integration project, which remains the most suc ssful $\mathrm{j}$ Africa peared in the colonial period in 1910 the South African Custom Jn- ACU) It consists of South Africa, Botswana, Lesotho, Namibia and Sway nd. Afte he rievement of political independence the agreement was signed aga in 99 , but nu by the colonial authorities, it was signed by sovereign countries. This union almost a whole customs union with free movement of goods and free tra sit through the to-itory of South Africa, led by the leader - South Africa, has a signific nt impace n determining the principles of the common commercial policy. The four cou tries (exc pt Botswana) are included in the common area of South African ran rency

Nowadays, it was registered 14 tegr. $n$ unions, which is very attractive for future cooperation of other foreiøn coun i The largest modern regional integration organizations were presented $\mathrm{Tab}: 1$.

Table 1: The largest dern onal intugration organizations of developing countries

\begin{tabular}{|c|c|c|}
\hline № & Name a d of organiz on & Members \\
\hline 1 & & $\begin{array}{l}11 \text { countries - Argentina, Bolivia, Brazil, } \\
\text { Venezuela, Columbia, Mexico, Paraguay, Peru, } \\
\text { Uruguay, Chili, Ecuador }\end{array}$ \\
\hline & & $\begin{array}{l}13 \text { countries - Antigua and Barbuda, Bahamas, } \\
\text { Barbados, Bellies, Dominica, others }\end{array}$ \\
\hline 3 & & $\begin{array}{l}5 \text { countries - Bolivia, Venezuela, Columbia, Peru, } \\
\text { Ecuador }\end{array}$ \\
\hline 4 & $\begin{array}{l}\text { Sow vern Common Market (MERCOSUR) - } \\
\text { since } 1991\end{array}$ & $\begin{array}{l}4 \text { countries - Argentina, Brazil, Paraguay, } \\
\text { Uruguay }\end{array}$ \\
\hline \multicolumn{3}{|c|}{ Integration organizations of Asia } \\
\hline 5 & $\begin{array}{l}\text { Economic Cooperation Organization (ECO) - } \\
\text { since } 1964\end{array}$ & $\begin{array}{l}10 \text { countries - Afghanistan, Azerbaijan, Iran, } \\
\text { Kazakhstan, Kirgizstan, Pakistan, Tajikistan, } \\
\text { Turkmenistan, Turkey, Uzbekistan }\end{array}$ \\
\hline 6 & $\begin{array}{l}\text { Association of South East Asian Nations } \\
(\text { ASEAN) - since } 1967\end{array}$ & $\begin{array}{l}6 \text { counties - Brunei, Indonesia, Malaysia, } \\
\text { Singapore, Thailand, Philippines }\end{array}$ \\
\hline
\end{tabular}




\begin{tabular}{|l|l|l|}
\hline 7 & Economic Cooperation of BIMST - since 1998 & $\begin{array}{l}5 \text { counties - Bangladesh, India, Myanmar, Sri } \\
\text { Lanka, Thailand }\end{array}$ \\
\hline 8 & $\begin{array}{l}\text { East African Community (EAC) - since 1967, } \\
\text { and since 1993 }\end{array}$ & 3 countries - Kenya, Tanzania, Uganda \\
\hline 9 & $\begin{array}{l}\text { Economic Community of West African States } \\
\text { (ECOWAS) - since 1975 }\end{array}$ & $\begin{array}{l}15 \text { countries - Benin, Burkina-Faso, Gambia, } \\
\text { Gana, Gvinea, Gvinea Bisau and others }\end{array}$ \\
\hline 10 & $\begin{array}{l}\text { Common Market for Eastern and Southern } \\
\text { Africa (COMESA) - since 1982 }\end{array}$ & $\begin{array}{l}\text { Namibia, Mozambique, Uganda, Malawi, } \\
\text { Rwanda, Zambia, Swaziland, Zimbabwe and } \\
\text { others }\end{array}$ \\
\hline 11 & Arab Maghreb Union (UMA) - since 1989 & $\begin{array}{l}5 \text { countries - Algeria, I Ya, Maurn } \\
\text { Morocco, Tunisia }\end{array}$ \\
\hline
\end{tabular}

The process of global changes in migration flows in the XI c atury. During the analyses of the global integration process, it's necessary to chtify tende of global changes in migration flows in the XXI century. Nowada , Migration as ecome a more dynamic and complex phenomenon, which is connectea with tonly social and economic reasons. According to International Labour Organiz's data, a ut a third of migrants in the world fall out of government control. Migratio control is heing passed from the Ministries of Labour to Ministries of Home Affairs in more nd more c intries. Thereby, the emphasis of the migration policy moves from labour marke gulation of the national security.

Between 2005 and 2010, the \& migram low increased by 1.8 percent annually. The growth rate of the migran por an in less developed regions was two percent, while in more develop oions is indicator was 1.7 percent. As a result, the number of migrants increase by 24 million people in $2005 / 10$.

According to the esth tion of 0 United Nations Organization, the Department of Economic and Soci Affairs, ne flow of 2.7 million people move from developing to developed countries $\mathrm{N}$ - year. Tha outh of the Sahara loses approximately 360000 people annually as a reailt of mis ation. The real interest for demographers makes the variable growth in the of the move nnt (migration), used to identify where the points of pressure are suppos to be the future. It should be noted that in 2005/10 the net migration rate in Australia incr a by $48>00$ people, while in the US it increased by 4.6 million people.

in 60 th nu ber of international migrants in developing countries reached 44 $\mathrm{m}$ (ion $\mathrm{p}$ an in developed countries, it reached 32 million people (Table 2). If in 60 more then $57 \%$ of all the migrants lived in less developed regions, in 2000 this numba vas only 37\% (Migration Information Source, 2011).

Table 2: International migration in the main regions, 1960 - 2000 years

\begin{tabular}{|c|c|c|c|c|}
\hline & \multicolumn{2}{|c|}{$\begin{array}{c}\text { The number of international } \\
\text { migrants (millions) }\end{array}$} & \multicolumn{2}{c|}{$\begin{array}{c}\text { Distribution of international } \\
\text { migrants by regions (\%) }\end{array}$} \\
\hline Main regions & $\mathbf{1 9 6 0}$ & $\mathbf{2 0 0 0}$ & $\mathbf{1 9 6 0}$ & $\mathbf{2 0 0 0}$ \\
\hline World & 75,9 & 174,9 & 100 & 100 \\
\hline Developed countries & 32,1 & 110,3 & 42,3 & 63,1 \\
\hline $\begin{array}{c}\text { Developed countries, } \\
\text { not including the USSR }\end{array}$ & 29,1 & 80,8 & 38,4 & 46,2 \\
\hline
\end{tabular}




\begin{tabular}{|c|c|c|c|c|}
\hline Developing countries & 43,8 & 64,6 & 57,7 & 36,9 \\
\hline Africa $^{\text {Asia }^{\mathrm{a}}}$ & 9 & 16,3 & 11,8 & 9,3 \\
\hline $\begin{array}{c}\text { Latin America and the } \\
\text { Caribbean }\end{array}$ & 29,3 & 43,8 & 38,6 & 25 \\
\hline North America & 6 & 5,9 & 8 & 3,4 \\
\hline Oceania & 2,1 & 40,8 & 16,5 & 23,3 \\
\hline Europe & 14 & 5,8 & 2,8 & 3,3 \\
\hline Republics of the USSR $^{\mathrm{b}}$ & 2,9 & 32,8 & 18,5 & 18,7 \\
\hline
\end{tabular}

Note:

${ }^{a}$ Not including Armenia, Azerbaijan, Georgia, Kyrgyzstan, Tajikistan, Turkm-astan, and Uzbekistan.

${ }^{b}$ Not including Belarus, Estonia, Latvia, Lithuania, Moldova, Russia, an Ukraine.

The collapse of the socialist system gave an impulse to ma geograph ni ation in Europe and Central Asia; first of all, to transboundary mo ment the population within the bounds of this region, migrant outflow from it a d a ain mintow from other regions. The formation of many new coup s in the ac of broken-up USSR and Yugoslavia created a phenomenon of mult.ple "s tistical migrants", in other words, citizens who live in a county for a long tir hut were rn in another, and who could not move in fact, but at the same time $y$ ould belong to the category of migrants in accordance with the UN procedures. Mig tion in E stern Europe (including the Baltic States) and CIS countries is considered to signifi ant according to international standards. Most of the emigratory flo am Ear European countries (42\%) are directed to Western Europe, while the fil $1 \mathrm{de}$ tion for most CIS emigrants are other CIS countries (80\%). The Unito ingdo becoming one of the leading countries of accepting migrants from coy ciles th at ente d the European Union.

Nowadays the main p nts $9 \mathrm{mg}$. nt movement take place in Mexican-American, Chinese and Russian, d also ropean and Eastern European regions. The analyses of the migrant flows in world sca, were introduced in Table 3.

\begin{tabular}{|l|l|}
\hline & Table 3. The main characteristics of migration flows \\
\hline From Mexico to the USA & $\begin{array}{l}\text { Canada turned out to be very attractive for professional emigrants from Asia. Many } \\
\text { leave their families in Canada and fly back to work to Asia. }\end{array}$ \\
\hline Fromy people from Asian countries, especially from Fujian province in China.
\end{tabular}




\begin{tabular}{|c|c|}
\hline Immigration to Venezuela & The "oil treasure" of Venezuela attracts many immigrants. \\
\hline From South America to Japan & $\begin{array}{l}\text { Japanese are ready to accept people who respect Japanese customs and whose } \\
\text { grandparents emigrated from Japan to Brazil and Peru. Japan has about } 287000 \\
\text { Brazilians and also } 56000 \text { Peruvians. In Hamamatsu city, there are } 19000 \\
\text { Brazilians, many of whom found work at plants in the industrial city. }\end{array}$ \\
\hline From Paraguay to Argentina & $\begin{array}{l}\text { Paraguay is one of the poorest countries in South America. Neighboring Argentina } \\
\text { is one of the alternatives, where many educated women work as domestic workers. }\end{array}$ \\
\hline $\begin{array}{l}\text { From Bolivia and Peru to } \\
\text { Argentina }\end{array}$ & $\begin{array}{l}\text { People from neighboring for Argentina countries work as construction workers, } \\
\text { domestic workers, or work under inhuman conditions at garment factory in Buenos } \\
\text { Aires. }\end{array}$ \\
\hline From South Asia to the UK & $\begin{array}{l}\text { Indian subcontinent was an important source of immigrants to the UK. In the } 1960 \text {-s } \\
\text { British government has begun to close the doors, so that most of arrived again unite } \\
\text { with other family members nowadays. }\end{array}$ \\
\hline From China to Europe & $\begin{array}{l}\text { Many Chinese traveled by air to Moscow, and then, by cont and way, to a the } \\
\text { Eastern Europe in order to reach Western countries. }\end{array}$ \\
\hline From Turkey to Germany & 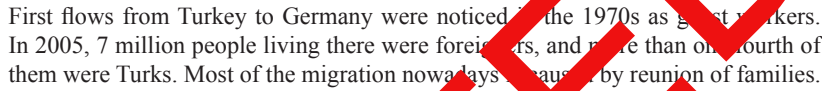 \\
\hline From Morocco to Spain & $\begin{array}{l}\text { About } 2000 \text { people a year die } \\
\text { Europe. }\end{array}$ \\
\hline From Africa to France & $\begin{array}{l}\text { The largest source of immigrants in France is its } \\
\text { out of } 138000 \text { immigrants, colonies in Africa. In } 1998 \\
\text { and Mali (in the past - Zai. }\end{array}$ \\
\hline Western African flows & $\begin{array}{l}\text { Côte d'Ivoire (the country Western Afri ) attracts workers for their plantations } \\
\text { of cocoa and palm oil. By th nid-1990 about one fourth of the work force was } \\
\text { immigrants, ha }\end{array}$ \\
\hline $\begin{array}{l}\text { From Zimbabwe and } \\
\text { Mozambique to South Africa }\end{array}$ & $\begin{array}{l}\text { South Africa vary from } 2 \text { to } 10 \text { million people. } \\
\text { are from Zimbabwe. }\end{array}$ \\
\hline «White flight» from $s$ & \\
\hline $\begin{array}{l}\text { From } \mathrm{S} \\
\text { States }\end{array}$ & $\begin{array}{l}\text { ir } 200000 \text { people from Sri Lanka cross the borders in search for work. } \\
\text { of them are women, migrating as housemaids to the Near East, as a rule. }\end{array}$ \\
\hline $\begin{array}{l}\text { From Eg } \\
\text { States }\end{array}$ & $\begin{array}{l}\text { rst exporters of workforce to reach oil cou } \\
\mathrm{m} \text { in } 1970 \text { to the present day. }\end{array}$ \\
\hline & $\begin{array}{l}\text { In } 2002 \text { there were } 3.1 \text { million Indians engaged in oil export in the countries of the } \\
\text { Persian Gulf, including } 1.5 \text { million people in Saudi Arabia, } 950000 \text { in the UAE } \\
\text { (Dubai), and } 300000 \text { in Oman. Half of these migrants are from Kerala, } 1.8 \text { million } \\
\text { people are from Bangladesh, one million people are from Pakistan, and } 900000 \\
\text { people from Sri Lanka. }\end{array}$ \\
\hline East is to & $\begin{array}{l}\text { Thailand has about one million immigrants, most of whom are agricultural workers } \\
\text { from Burma (Myanmar). }\end{array}$ \\
\hline $\begin{array}{l}\text { Emigrants om South Asia } \\
\text { moving to the East }\end{array}$ & $\begin{array}{l}\text { India, Bangladesh, and Pakistan send many workers to South-East Asia, particularly } \\
\text { to Singapore, as a rule, for working on building sites. }\end{array}$ \\
\hline From Indonesia to Malaysia & $\begin{array}{l}\text { Indonesia has about one million illegal workers from Malaysia, most of whom are } \\
\text { men working on plantations, but there are also women who work as housemaids. }\end{array}$ \\
\hline Australia diversifies & $\begin{array}{l}\text { Asian migration to Australia from China, Vietnam, Philippines, and Indonesia } \\
\text { makes this country more ethnically diverse. Many Asians and other migrants arrived } \\
\text { also by boats as refugees. }\end{array}$ \\
\hline Flows between China and Korea & $\begin{array}{l}\text { In the end of 2006, Korea had } 186894 \text { illegal workers, most of whom were ethnic } \\
\text { Chinese and Koreans. North Koreans migrate also to China and then, often go to } \\
\text { South Korea. }\end{array}$ \\
\hline
\end{tabular}




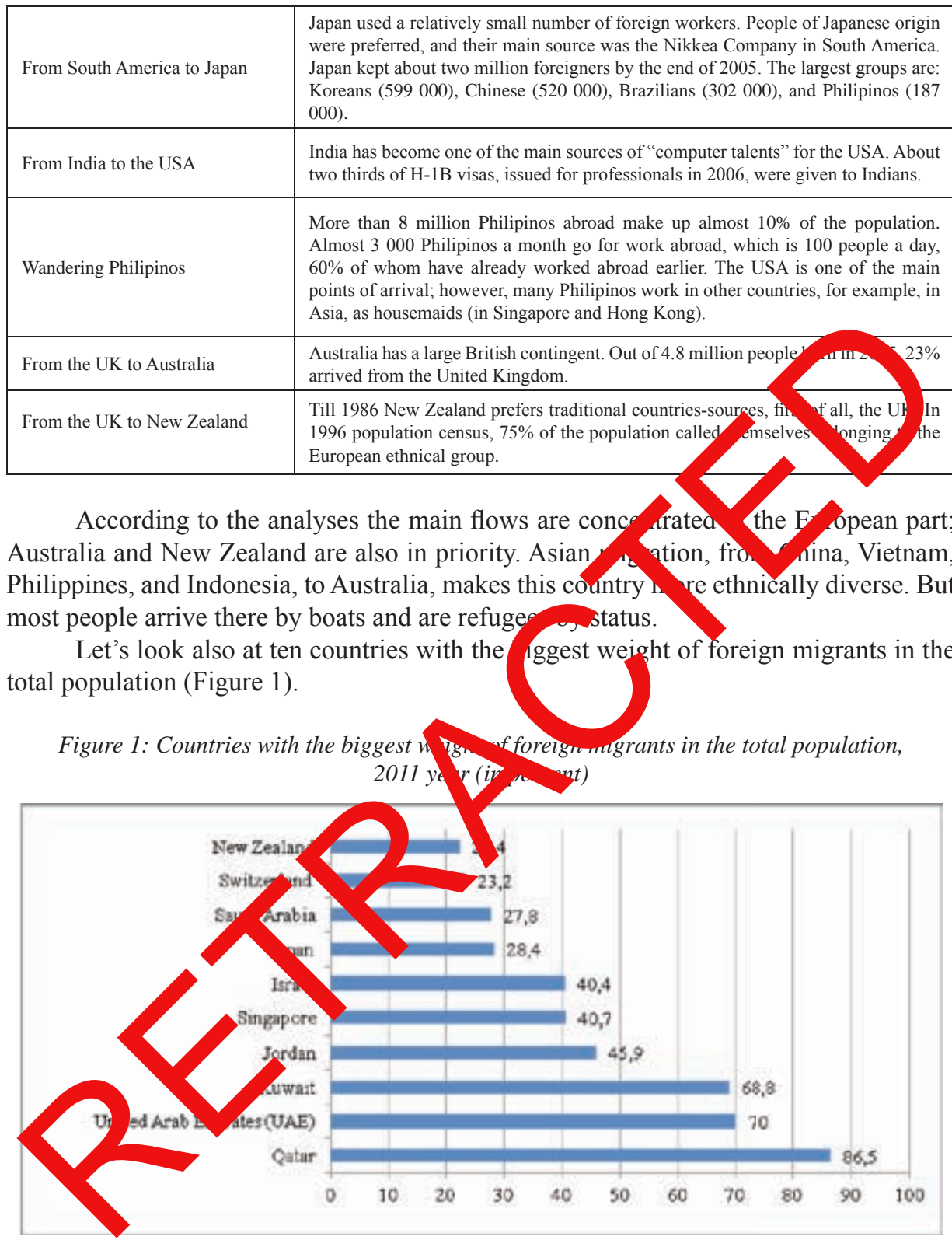

Qatar takes the first place, having $86.5 \%$, the second country is the UAE (70\%), and the third is Kuwait (68.8\%).

Based on the conducted research, we determined two leading countries with the biggest number of migrants during the analyzed period. These are the USA, with the number of 7980 thousand people from 1995 to 2000, and Russia, with the number of 2220 thousand people from 1990 to 1995 . What about 2005/10 period, the USA took 
the first place by the number of migrants with the 5050 thousand people, Spain was the second with 1750 thousand people, and Italy was the third with 1650 thousand people. We shouldn't forget about Canada, which attracts many migrants with beneficial conditions of purchasing real estate and the following easy way of getting the citizenship.

The main structural changes in the international migration should be noted. First is that during the last decades, Western and Eastern Europe have become the points of destination for immigrants from Asia, the Near East, and Africa, and at the moment of the USSR collapse in the 1990s, Western Europe went through the migration flows from Eastern Europe and the former Soviet Union. As a result the net migration in the European Union increased from 200 thousand people in the 1980s to more than one million people in 1989/93, but then it decreased again by 640 thousand people in 1994/9

The second key structural change was an increase of immigratic from As and the beginning of immigration from Africa. Asian migrants arrived from dia, Paki an, China, Korea, Philippines, Vietnam, and other places. The exampl of Asian mig tion could be observed in Europe, with African immigrants and iv nigrap from Near East.

Development of integration process in Asia-Pac c Region nd $\boldsymbol{P}$ assia. During the pace of economic development and rapid economi gro $h$ in the A a-Pacific region have led to the need to create effective inter-regional integration roups (APEC, ASEAN, ADB, SAARC, ESCAP, ASEM, ARF). Yet, operational sucess of the currently existing organizations could be called into que ion. The alysis showed that the stated objectives have not been fully achieved by an of the $c$ ganizations. Moreover, if in

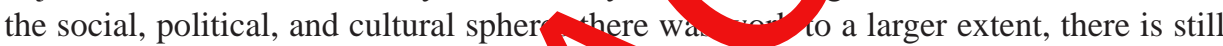
minimal cooperation in the economic sp ere.

It is necessary to formulata-disting features of NEA in order to estimate the processes of integration occu hg neA d define perspectives of the given region.

Firstly, this region di nguis arp,erk in economic growth for the short period of time. It determines $\mathrm{n}$-ded contour of partner relations.

Secondly, on backgrou of non-developed contour of partner relations often changes of integrau on p c cesses are observed - growth of rates of saturation of regional space by new artner agre vents. The region becomes more and more "integrationintensive"

The $\mathrm{t}$ d ature -distinction or similarities in branch structure of gross national prody now ander in influence on an increase of volume of mutual trade between co atries martne The fact of joint participation of the countries of Northeast Asia (A) ono gding block is not reflected in any way in volume of trade between these untries. It proves that the neighbouring countries will not inevitably have the consider le volume of mutual trade.

It argues that many trading blocks are results of the political decision, but not objective economic process. That defines the fourth feature of integration processes in the region. Especially brightly it can be looked after on an example of the Tumen River Project, which declared as the political decision, without the proved economic preconditions.

For sustainable integration processes are necessary, so-called initial factors, historically formed trade relations, the sizes of the countries, purchasing power on the basis of which strong trade unions can be build up. 
Today in NEA we observe the countries, which actively compete among themselves in the international market and do not consider each other as strategically important partners. Cooperation in the solving of problems of peace and security, preservation of the environment in a region does not necessarily demand integration groupings, in particular, trading preferences.

The fifth feature - asymmetry of partners in integration of Northeast Asia. The size of their markets and a level of technology are not balanced. It is impossible to attribute to a category of the symmetric countries, for example, Russia, China, Japan, and the Republic of Korea. The intensification of regional integration has strengthened amplitude of deviations of subjects of integration on their weight categories. Economic asymmetry of partners has considerably increased because of an integrat licy of China, actively began to develop regional trade. Reached the appropriat greemen with Hong Kong, China is aimed to establish three foreign agreements with $\lambda_{a}$ an and $\mathrm{K}$ rea and negotiates for the similar agreement with ASEAN.

Integration changes the model of international division factor and, h of all, natural resources. The relative advantages of possession of $y$ tura surces replaced by advantages of those who can get and use them. It is $\mathrm{kn}$ on that th with rich natural resources lag behind in rates of economic grow 1. In hat case, thre is a question: whether it is necessary for Russia to be guided by an integratio. vector if the structure of export will cause delay of rates of economic de clopment.

The regional future of Russia becomes 1 ore predic $d$ and less arbitrary, not only geographically, but also economically. We est ate statis cally the factors influencing on volume of export and import on axpamp antries - participants ASEAN 5 and NEA (China, Korea, and Japan). The is of the analysis is the gravity model (trade between two countries demands on size (GNP, population, territory, etc.) and operational costs (distance be reen he cou tries, cultural similarity etc.).

Being based on prek inary th on test of the gravity model it is possible to draw some conclusions the portance of some factors.

First of all, it i ecessary vay attention that the variable reflecting participation of the countries in ASE, $Y$ appeared insignificant, i.e. the fact of joint participation of ASEAN coun es in one th ling block is not reflected in any way in volume of trade between th courries. The same conclusion can be made as to variable reflecting distance be ree two countries that supports the conclusion that the neighbouring count 10 no neces arily have the significant volume of mutual trade. Gross national pr act of the par and a share of a secondary sector in gross national product of the co try no nfluence significantly on volume of import. In other words, distinctions or sin arity in branch structure of gross national product do not render influence on the incro of volume of mutual trade between countries ASEAN 5 and NEA and their partners.

Estimated functions look as follows:

Ln IMP $=\alpha+\beta 1 L n G D P^{H}+\beta 2 L n G D P^{P}+\beta 3 L n P G D P^{H}+\beta 4 L n P G D P^{P}+\beta 5 L n$ SHAREIMP + $\beta 6$ Ln PS $S^{H}+\beta 7 L n P S^{P}+\beta 8 L n S S^{H}+\beta 9 L n S S^{P}+\beta 10 L n D I S T+\beta 11 L n D$ $+\varepsilon,(1)$

Ln TTRADE $=\alpha+\beta 1 \mathrm{Ln} G D P^{H}+\beta 2 \mathrm{Ln} G D P^{P}+\beta 3 \operatorname{Ln} P G D P^{H}+\beta 4 \mathrm{Ln} P G D P^{P}+$ $\beta 5 \operatorname{Ln}$ SHARETTRADE $+\beta 6 \operatorname{Ln} P S^{H}+\beta 7 \operatorname{Ln} P S^{P}+\beta 8 \operatorname{Ln} S S^{H}+\beta 9 \operatorname{Ln} S S^{P}+\beta 10 \operatorname{Ln} D I S T$ $+\beta 11 \operatorname{Ln} D+\varepsilon,(2)$ 
Where $\alpha$ - a constant (a constant variable), and $\varepsilon$-regression balance.

As explaining variables, the following variables were chosen:

$G D P^{H}-$ GDP of country A,

$G D P^{P}-$ GDP of country B,

DIST - distance between A and B,

$P G D P^{H}$ - GDP per capita in A,

$P G D P^{P}$ - GDP per capita in B.

SHAREIMP (SHARETTRADRE) - a share of import (or the sums of export and import) the countries A from the country B in a total volume of import (or the sums of export and import) the countries A,

$P S^{H}$ - a share of initial sector in cumulative gross national product of ${ }^{1}$ ntry A,

$P S^{P}$ - a share of initial sector in cumulative gross national product the coun $\mathrm{y} \mathrm{B}$,

$S S^{H}$ - a share of a secondary sector in cumulative gross nationa roduct o the country A,

$S S^{P}$ - a share of a secondary sector in cumulative gros nation produ of the country B,

$D$ - the fictitious variable reflecting participation both cou ries one trading block (the variable accepts value "1" if both count os aSEAN articipants, and value " 0 " otherwise).

Besides standard variables (i.e. GDP and distance), directly reflecting the size and transport costs, we chose parameters GDP per fapita (1) flecting the general level of economic development, the level of yages in coun $y(2)$; indexes of a share of primary and secondary sectors in GDN o, howing a level of industrial development of the country; and a qualitative variable $f \mathrm{p}$ ation of the countries in the uniform trading block (3). Results of th imati of mentioned regressions are submitted in Table 4.

\begin{tabular}{|l|l|l|l|l|}
\hline & & \multicolumn{3}{|c|}{ Regression $(2)$} \\
\hline \\
\hline GD
\end{tabular}




\begin{tabular}{|l|l|l|l|l|l|}
\hline $\begin{array}{l}\text { Share of secondary sector in GDP } \\
\text { of A }\end{array}$ & $-0,27$ & $-1,831$ & $\begin{array}{l}\text { Share of secondary sector in GDP } \\
\text { of A }\end{array}$ & 0,03 & 0,198 \\
\hline $\begin{array}{l}\text { Share of secondary sector in GDP } \\
\text { of B }\end{array}$ & $-0,55$ & $-2,997^{* * *}$ & $\begin{array}{l}\text { Share of secondary sector in GDP } \\
\text { of B }\end{array}$ & $-0,52$ & $-3,114^{* * *}$ \\
\hline $\begin{array}{l}\text { Participation of countries in one } \\
\text { block }\end{array}$ & $0,45 \mathrm{E}+10$ & 0,094 & $\begin{array}{l}\text { Participation of countries in one } \\
\text { block }\end{array}$ & $-0,35 \mathrm{E}+11$ & $-0,657$ \\
\hline Number of observation & 712 & & Number of observation & 712 & \\
\hline Index of determination $\left(\mathrm{R}^{2}\right)$ & 0,9869 & & Index of determination $\left(\mathrm{R}^{2}\right)$ & 0,9867 & \\
\hline Fisher's criteria (F) & 49,613 & & Fisher's criteria (F) & 51,972 & \\
\hline
\end{tabular}

${ }^{1}$ - Meaning of coefficient when $\alpha=0,01$ marked $^{* * *}$, when $\alpha=0,05$ marked $^{* *}$.

The empirical analysis of countries ASEAN 5 and NEA has ce firmed the the formation of the trading block does not increase the volume of mutua trad Member hip in one trading union is the secondary factor in the development of atual trad whi can be amplified with a number of initial factors, such as historica form drade clations (in our regression it is reflected by a variable « a share of tpon the cor try A from the country B in total volume of import of the country the size of countries (a variable «gross national product»), purchasing pow (a viable «G. P per capita»). These variables reflect the scale of country markmand the n ket of the partner, and share of income spends for import.

The development of integration process has the a ect of indicator of economic openness of the country or region.

Asia-Pacific region has a great e. ance on growth that cannot attract the attention of researchers in the world. Low the important parameter has become the openness of the economy ( omic enness). In general, it can be identified as the level of involvement of th econ my on he country or region in the world economy. Its quantification is given $b$, the $r$ odu which produced in the country with that part of it which is taken oy and w the amount of goods and services, which is imported into the country an region. herefore, the summarizing quantitative measure of economic openness is the arcentage ratio of exports plus imports to GDP, or the share of foreign trade a percentage GDP. We can call this indicator of openness as the quota indicator $b$ ause $i s$ calculated by the relative sizes of export and import quotas - the ratio of the che of port and import to GDP. It should be noted that this indicator has ran lim tion and suggests addition other indicators (indicators of the capital $\mathrm{m}$ semen But, wnsidering the dominant role in the trade in the foreign economic rels. op of thindicator is the most significant.

e calculated the results of the comparative analysis of indicators of economic openness f regions. Before the crisis in 1997 year, Asia-Pacific region was ranked as the most open one in the world (Table 5). 
Table 5: The economic openness of the regions (before the crisis in 1997)

\begin{tabular}{|l|l|}
\hline Regions & Economic openness, \% \\
\hline South-East Asia & 130 \\
\hline North-East Asia & 60 \\
\hline Central and Eastern Europe & 55 \\
\hline Russia & 40 \\
\hline Latin America & 30 \\
\hline G-7 & 28 \\
\hline India & 25 \\
\hline
\end{tabular}

Sources: Emerging market indicators. 1996. The Economist, May 11 0.116.

Many experts believed that there was a high level of eco omic open ss the nine countries in Asia-Pacific region (Hong Kong, Singapore, jwan Aorea, Malaysia, Indonesia, Thailand, China, Vietnam) provide a high rate eco sic gro th of these countries during more than twenty years. These coy ies conth ed develop at relatively high rates - more than five per cent of GDP growt in the perrod from 1990 to 1996, before the period of crisis in Asia-Pacific

We say about the relatively high level co npared to other regions of the openness of Asia-Pacific region. From the end of XIX entury Ho g Kong and Singapore have always been the most openness economies in his regi n. During the 1960s, Japan, Korea and Taiwan were among the firs to duce tru stoms trade barriers and reduce restrictions on foreign exchange marke Tb SAN countries (Malaysia, Thailand, Indonesia, Philippines) follower the sa way of liberalization of foreign trade, but a bit later (in the 1970s). The oearch rs not that although there is no comparable data, but in 60-70 years, the econ vies As Pacific region were more openness than other developing countries.

Foreign trad 1. aralizatio and the increasing level of Asia-Pacific region's openness continued in the 980 s. Its role in improving the overall level of openness in the region and ha played an eve of changing the Chinese economic strategy and its active involveme in the orld economy. But an even more significant role in achieving a higher opening in th gion w played a one-sided nature of the liberalization of its external relat iss. Uurin this criod, it was developed the concept of openness regionalism and E t-Asia vle inugration, as opposed to the concept of discriminatory regionalism and Io Amucan-style integration. These concepts are the different approaches to the par nent matrix, and the border between them is through a unilateral reduction in foreign tivde barriers, and therefore anticipating growth of openness of the economies of Asia-Pacific region.

However, in the late 1980s liberalizing included almost all the other developing countries in the world, and many developed countries reduced trade barriers by the unusual way, unilateral procedure.

It is likely that in this period the quota indicator of economic openness (ratio of exports and imports to GDP) loses its fundamental role. Since the late 1980s, it has appreciates the openness of the economy solely from the functional point of view, from the perspective of 
functional openness. This position is due to the "functioning" of foreign trade, necessary for the economy of the country and it is estimated to be the part of GDP that goes through the channels of foreign trade. This position which was occupied by the country has taken in the international division of labor and other resources in accordance with the relative availability of resources by the Heckscher - Ohlin theory (Appleyard, Field \& Cobb , 2006).

But from the moment when the functional openness of the economy is defined, the measureofitsdependence onforeigneconomic relations developed furtherreduction oftrade barriers may prevent the growth of quota indicator. That is why the most liberal economy of developed countries has the lowest rates of openness on the quota indicator. By the incorrect use we can say when we indicated the fact that the present performance of the economy of North Korea is more open than the economy of Japan and other develor untries. It should be said about the necessity of another dimension of economi openness the institutional openness. In general, the institutional openness is the $o_{1}$ nness of the institutions of the country to the outside world. If we highlight t $1 /$ econon asp et of openness, the first thing we should have in mind is such institu ons as ade, in stment and foreign exchange regimes of the country.

\section{Conclusion}

What is it necessary for Association to urn into onomically significant? It is impossible to answer this question shortly an unequiy cally. It is obvious that the principle of "laissez-faire" will not so we prob. Ne need active participation of the governments of all countries in regu tion arivate and public sectors. Despite all the efforts of ASEAN participar to dec tariffs and liberalize markets for foreign business since 1995, there $\mathrm{j}$ a ple ty of on-tariff barriers. Therefore, for the given countries the most logical s 1 be ver ment of cooperation in the field of unification of customs rules and th other s regulating trading activity.

It is necessary ove asid vultilateral, instead of regional integration. A position of authors - it is more eft tive to be included in the integration process not on the basis of bilateral ag ements, espo illy with the country surpassing on the sizes of the market and a level tech ologies, but on a basis the Pan-Asian zone of free trade, ideally the Pan-Asian-A io zone $g$ free trade.

Do des anor cobstacles to the creation of the Northeast Asian trading block in ne nea anc $\mathrm{Ch}$ a. Ho ever, according to calculations of some experts, creation of this zone of fre rade with participation of Japan, South Korea and China will be favorable to all countries Certainly, Japan and South Korea will win from this union considerably, but for China the positive effect will be significant.

We can say that the serious researching work on unification and the liberalization of domestic markets is required otherwise and the unions will be extremely political and will not bring any economic benefit.

North-East Asia is far away from the integration process for a long time in AsiaPacific region. In this sub region bilateral type of relations burdened with a heritage of animosities and deep political distinctions dominates. Nevertheless, new style of mutual economic cooperation between the countries is gradually formed. The formation of such 
style began with the leading role of a private sector in Japan, and then were South Korea and Taiwan, and then other countries of the sub region have followed.

The potential union between China, Japan and South Korea will be economically and politically significant with its share in world GNP about $20 \%$. The index of trading complementarity (ITC), which reflects the electiveness of trade between the certain countries in comparison with world trade, proves this conclusion. ITC for NEA countries exceeds the level of world trade; that is why regional trade will promote regional integration, considering the fact that the NEA countries do not participate in other sub regional agreements. The potential union of China, Japan and South Korea will cover about their half of the trade, which is carried out by these countries, so the preferential agreement on trade will bring to the countries essential benefit. However, it should be taken into consideration ane trade volume of Japan with USA exceeds the total amount of trade of Japan ith its po ntial partners. China with South Korea has also the significant volume of th le with I SA: totally $23.8 \%$ of import and $15 \%$ of export. Therefore, at a deepenir of coop tion the framework of the NEA, it is necessary for participants to take inte coun imerid actor.

Certainly, there is a question of a role of Africa in thi glo ategration process. During our analyses we identified the obvious historical is ation of s re on from main integration process. But based on the research data of gra on flows hafrica and other regions we can say about the beginning of global changes in th rld polarization. African countries became more attractive for cooper ion and collaboration of Asia-Pacific Region countries. During our research, we fo low the $\mathrm{h}$ torical period of integration unions in Africa and can say about its intensifid ion.

It is necessary to note that Afri integran have the similar features of development as a lot of Asian union had heginning stage of its development. And nowadays, in the period of active $n$ globalization and integration tendencies, it's important not to lose the oss? lity o creating the integration union between the countries of Asia and Afric which an nut al interests.

agary - V.K., \& Ravenhill, J. (2001). Undermining the WTO: The Case against open sctoralism. Asia-Pacific Issues.

App vard, Field, \& Cobb. (2006). International Economics (5th ed.). McGraw-Hill Irwin.

Calder, K., \& Ye, M. (2004). Regionalism and Critical Junctures: Explaining the "Organization Gap" in Northeast Asia. The Journal of East Asian Studies, 4(2), 191-226.

Chang Jae, L. (2000). Northeast Asian Economic Cooperation: The Need for a New Approach. NIRA Review, 7(4), 5-10.

Chase, K.A. (2003). Economic Interests and Regional Trading Arrangements: The Case of NAFTA. International Organization. 57(1), 137-174. 
Dent, C. (2003). Networking the Region? The Emergence and Impact of Asia-Pacific Bilateral Free Trade Agreements'. The Pacific Review, 16(1), 1-28.

Emerging market indicators. (1996). The Economist, May 11, p.116.

Encarnation, D.J. (1999). Asia and the Global Operations of Multinational Corporations. In D. J. Encarnation (Eds.), Japanese Multinationals in Asia: Regional Operations in Comparative Perspective (pp. 3-13). New York: Oxford University Press.

Ernst, D. (1997). Partners for the China Circle? The Asian Production Networks of Japanese Electronics Firms. The Berkeley Roundtable on the International Economy (BRIE) Working Paper 91. Berkeley: UC Berkeley.

Higgott, R. (1998). The Pacific and Beyond: APEC, ASEM and Rec onal Eco mic Management. In G. Thompson (Eds.), Economic Dynamism in in Asia-Pa fic: The Growth of Integration and Competitiveness (pp. 335-35, Londo Rout dge

International Monetary Fund. (2011). World Economic Outh kat ase, Ap.1 2011, Nominal GDP list of countries, Data for the year $20 \%$.

International migration and human rights, and devel ent in Lat nerica and the Caribbean. (2006). «ECLAC», available at hup://w reclac.org/publicaciones/ $\mathrm{xml} / 4 / 24024 / \mathrm{DGI}-2303 \% 28 \mathrm{SES} .31-11 \%$ igration- b.pdf, retrieved on 21 June 2013.

Keeley, B. (2009). International Migration: 1 e Human ace of Globalization. OECD, September, 3-4.

Kleyn, G. (2010). Global populat $n$ aments critical issue of $21^{\text {st }}$ Century. Independent strategic analusis of "alias global interests, November 18, 3-4.

Jones, M. D., \& Smith M.J R. (2 07). N king Process, Not Progress. ASEAN and the Evolving East Asiar regio ato dernternational Security, 32(1), 148-184.

Milner, H. (1997). I ustries, overnments, and Regional Trade Blocs. In E. Mansfield \& H. Milne a ), The Po tical Economy of Regionalism. New York: Columbia University Press.

Pempel, T . 2003. 'Restru uring Regional Ties' in A. Macintyre, T. J. Pempel and J. Ra nhill cds). Crisis as Catalyst: Asia's Dynamic Political Economy, 164-80, Ithacà ornell niversity Press.

avent 1, J. J2). A Three Bloc World? The New East Asian Regionalism. erm ronal Relations of the Asia-Pacific, 2, 167-195.

Ra. mnova, L.L. (2012). The problems of integration mechanism of developing c yntries. Proceedings of MGLU, №542, 40-52.

Skvarya L.V., \& Zakharova. E.V. (2012). 'Economical integration of developing countries in globalization period', available at http://www.m-economy.ru/author. php?nAuthorId=1384, retrieved on 20 June 2014.

Southern African Customs Union (SACU), available at http://www.sacu.int/list. php?type=Annual\%20Reports, retrieved on 21 June 2013.

UNCTAD Handbook of Statistics 2003. International Trade Statistics 2003. WTO, Geneva. 